\title{
Categorization of constructional and technical condition for processing of brownfield identifying studies
}

\author{
Zuzana Kramářová ${ }^{1, *}$ \\ ${ }^{1}$ Faculty of Technology, The Institute of Technology and Business, Okružní 517/10, 37001 České \\ Budějovice, Czech Republic
}

\begin{abstract}
The issue of brownfield revitalization is one of very actual topics in the area of the sustainable development and construction. The registration of localities characterized as brownfields is addressed within compiling and updating Land Analytic Background of municipalities in the Czech Republic. However, it is very unsatisfactory for practical revitalization needs, and it is partly due to disunity in the data recorded in different locations in different administrative territories, and also the small range of such data. Therefore, so called "Brownfield Identifying Studies" are important to compile in particular administrative districts at the level of municipalities with extended jurisdiction. These studies are tasked with not only identifying brownfields $=$ localizing but also keeping database of them with closer data which can make potential investor's decision much easier. Constructional and technical condition is one of the assessed and registered data when compiling and cataloguing Brownfield Identifying Studies. As these databases are used by large - unprofessional public it is necessary to describe the condition as simply as possible, for instance to express it by a numerical marking. The pitfalls of brownfield constructional and technical condition classification are described in detail in the contribution.
\end{abstract}

\section{Introduction of Brownfield Issue}

The issue of brownfield revitalization is one of the very actual topics in the area of sustainable development and construction. The first step of successful revitalization is timely compiling all available information about a certain location, eventually chosen locations in order to be possible to eliminate negative effects of the certain location in time, e.g. area contamination, bad constructional and technical condition of the objects, inappropriateness of the new functional usage with respect to its surroundings, ...For these purposes it is useful to register brownfields in the area and when the conditions of one of the brownfield are not convenient, another object can be brought in to a potential investor who can be protected from leaving the certain area.

The registration of localities characterized as brownfields is addressed within compiling

\footnotetext{
*Corresponding author: 19511@mail.vstecb.cz
} 
and updating Land Analytic Background (UAP) of municipalities in the Czech Republic. This is legally enshrined in Law no. 183/2006 Sb on Planning and Building Code (Building Law) [1], especially in its processing Decree No. 500/2006 Sb., on Land Analytic Background, Urban Planning Documentation and Register Methods of Planning Activities [2] where there are observed phenomena listed and updated in UAP of municipalities in annex 1 part A. Brownfields belong among phenomena no.4, "areas to recover or reuse of devaluated territory". UAP update takes place every 2 years in the Czech Republic as appears from Building Law.

However, it is very unsatisfactory for practical revitalization needs, and it is partly due to disunity in the data recorded in different locations in different administrative territories (a processor differs from a processor, even Administrative District differs from another Administrative District - according to available finance spent on UAP update), and also the small range of such data. This range is usually limited to a name of location, serial number, cadastral territory and plot number, original use and constructional and technical condition of the location. In many cases there are not known even all these most basic data. Therefore so called "Brownfield Identifying Studies" are important to compile in particular administrative districts at the level of municipalities with extended jurisdiction. These studies are tasked with not only identifying and localizing brownfields (which means to discover them) but also keeping database of them with closer data which can make potential investor's decision much easier [3].

\section{Brownfield Identifying Studies}

Study for Locating Brownfields [4] was one of few studies done across the board. It was co-financed by Business and Investments Support Agency CzechInvest. The study was processed on the whole territory of the Czech Republic in years $2005-2007$. However, not only the different level of processing in different regions was its main insufficiency because the particular regions were except CzecInvest the project co-owners that did not unify observed information about particular locations but also its very most fundamental commission which was: "Find 200 brownfields in the region which floor area is larger than $500 \mathrm{~m}^{2}$ or ground area is larger than $1 \mathrm{ha}$ ". From this commission it is clear that the demand was not to find all brownfields meeting the asked parameters but exactly 200 . In some regions this led to integrating of properties that could not be definitely considered brownfields, somewhere else it happened that the number of locations was reduced (they were eliminated afterwards) or the research ended when the defined number was reached (a part of the territory was not been explored). Nevertheless, basic mapping of the issue condition on the whole territory of the Czech Republic was the indisputable benefit of the study including collection of more detailed information about the individual locations. In some regions this collection took place in several phases, in other ones conversely one phase only was done. For instance, in Region Hradec Králové there were 3 phases set in which previously got information was specified and searched again in every further phase. South Bohemian Region was an example of one phase only data collection there was collected more detailed information in one step but less amount only there. The study outputs were one of the sources at processing of National Brownfield Regeneration Strategy. Unfortunately, it has not been approved by the Government of the Czech Republic yet. 


\section{Categorization of Constructional and Technical Condition of Brownfields}

Basic purpose of the identifying studies is to gain a compact brownfield file = reusable areas which will be introduced to potential investors as an offer, and due to this file annexation of open landscape, especially agricultural land and valuable natural areas will be decreased. Nevertheless, it is not required to publish all data directly from a practical (data size) point of view and with respect to personal data protection. From experience at processing of brownfield identifying studies intended for practical needs in territory, multistage cataloguing demand has clearly arisen which means to create at least two-stage database. The first stage should be absolutely available for public, paper as well as electronic version which is remotely accessible would be ideal. This stage should contain basic information about the property/location, (lit. dissertation) - name, serial number, type, cadastral area, size/floor area, number of objects, condition primary evaluation, basic information about traffic and technical infrastructure, information about contamination, ownership type and information about greenness, and all completed with approximately 4 characteristic photographs and map position plot. The second stage should not be made open to public without an interested person being registered in advance because it can contain sensitive data as owner's phone numbers, e-mail contacts, information about liens, ... This stage has to more concretize the previous information thus for instance technical infrastructure concerning it is necessary to describe not only concrete connections existence but also their eventual capacity or nominal diameter, distance to possible connecting or connection lengths and their trace, eventual owners (when they are different from the brownfield owners), ...

Table 1. Brownfield constructional and technical condition classification scale at first cataloguing stage.

\begin{tabular}{|c|l|l|}
\hline evaluation & verbal evaluation & \multicolumn{1}{|c|}{ detailed description } \\
\hline 1 & excellent condition & $\begin{array}{l}\text { brownfield is possible to use immediately without any } \\
\text { change of functioning and any invests in repairs }\end{array}$ \\
\hline 2 & good condition & $\begin{array}{l}\text { brownfield needs minor building modifications or } \\
\text { common maintenance work that can be postponed } \\
\text { eventually (e.g. remediation of facade) }\end{array}$ \\
\hline 3 & worse condition & $\begin{array}{l}\text { most common condition - brownfield needs building } \\
\text { repairs (e.g. water spout exchange, inner water and drain } \\
\text { piping repair, electrical wiring, ..) }\end{array}$ \\
\hline 4 & bad condition & $\begin{array}{l}\text { brownfield cannot be used without large repairs (e.g. } \\
\text { roof timbers repair, remediation of damp supporting } \\
\text { structures, windowpanes, door panels, floors and interior } \\
\text { wall plasters, ... }\end{array}$ \\
\hline 5 & critical condition & $\begin{array}{l}\text { brownfield is in serious disrepair - supporting structures } \\
\text { are structurally unsound, making large complex repair or } \\
\text { demolition should be considered }\end{array}$ \\
\hline
\end{tabular}

Description of brownfield constructional and technical condition is one of important area of observed data especially for investors. Its processing should be integrated into both stages of catalogue information. Working on the assumption that the first stage database is 
used by large unprofessional public, it is necessary to describe such condition at first stage as simply as possible, for instance to express it by numerical marking. Most commonly used classification scale is marking form 1 to 5 , see Table 1 .

The disadvantage of this scale is that almost $2 / 3$ of brownfields get mark 3 -worse condition. Though the range of this category is large - from objects in relatively good condition that need most necessary repairs only for instance as interior wiring and piping up to objects quite devastated that need immediate intervention because atmospheric precipitations are leaking inside and that leads to initial damage of interior equipment, wiring, piping and floors. Other relatively common grade is grade 5 - critical condition. The other conditions are represented rarely.

Table 2. Example of evaluation of object condition.

\begin{tabular}{|c|c|c|c|c|}
\hline \multicolumn{3}{|c|}{ object parts } & evaluation & description/note \\
\hline \multirow{4}{*}{ roof } & \multicolumn{2}{|c|}{ covering and hydro-isolation } & 2 & covering changed in 2001 \\
\hline & \multicolumn{2}{|c|}{ supporting construction } & 1 & timbers reconstruction in 2001 \\
\hline & \multicolumn{2}{|c|}{$\begin{array}{l}\text { rain water drainage (spouts }+ \\
\text { sheet metal covering) }\end{array}$} & 2 & spouts OK, need to clean \\
\hline & \multicolumn{2}{|c|}{$\begin{array}{l}\text { outlets(chimney heads, breather } \\
\text { chimneys, ...) }\end{array}$} & 3 & $\begin{array}{l}\text { need to re-point and remediate chimney } \\
\text { slab }\end{array}$ \\
\hline \multirow{15}{*}{$\begin{array}{l}\text { upper } \\
\text { constru } \\
\text { ction }\end{array}$} & \multirow{4}{*}{$\begin{array}{l}\text { main } \\
\text { supporting } \\
\text { structures }\end{array}$} & horizontal & 2 & $\begin{array}{l}\text { beam ceilings - need to renew paints } \\
\text { against pests }\end{array}$ \\
\hline & & stairway & 2 & $\begin{array}{l}\text { wooden - need to renew paints against } \\
\text { pests }\end{array}$ \\
\hline & & vertical interior & 1 & brick \\
\hline & & perimeter & 1 & brick \\
\hline & \multicolumn{2}{|c|}{ perimeter coat } & - & - \\
\hline & \multirow[b]{2}{*}{ plasters } & outside & 4 & $\begin{array}{l}\text { north side façade is falling away, the } \\
\text { others have evident bulges }\end{array}$ \\
\hline & & interior & 3 & $\begin{array}{l}\text { ground floor is damaged by graffiti } \\
\text { artists, the other floors need to repair } \\
\text { partially - rare bulges. }\end{array}$ \\
\hline & \multicolumn{2}{|l|}{ floors } & 3 & $\begin{array}{l}\text { wooden - on ground floor significantly } \\
\text { damaged - need to change, on the others } \\
\text { can be repaired }\end{array}$ \\
\hline & \multirow{3}{*}{$\begin{array}{l}\text { panes and } \\
\text { panels }\end{array}$} & window & 4 & $\begin{array}{l}\text { significantly damaged on ground floor by } \\
\text { vandals, the others can be repaired by } \\
\text { glassing }\end{array}$ \\
\hline & & door & 5 & need to change, significantly damaged \\
\hline & & others & - & - \\
\hline & \multirow{4}{*}{$\begin{array}{l}\text { technical } \\
\text { building } \\
\text { equipment } \\
\text { installation }\end{array}$} & water piping & 5 & cracked by frost \\
\hline & & sewerage & 3 & $\begin{array}{l}\text { partially in order, branch with vertical } \\
\text { drainpipes blocked }\end{array}$ \\
\hline & & electro & 5 & $\begin{array}{l}\text { need to install all new - not fitting } \\
\text { current demands }\end{array}$ \\
\hline & & heating & 4 & central Heating - cracked by frost \\
\hline
\end{tabular}




\begin{tabular}{|l|l|l|l|}
\cline { 3 - 4 } & \multicolumn{1}{|c|}{ gas } & - & - \\
\cline { 2 - 4 } & others & - & - \\
\cline { 2 - 4 } & security elements (banisters, ...) & 2 & $\begin{array}{l}\text { forged - need to clean surface rust but } \\
\text { firm }\end{array}$ \\
\cline { 2 - 5 } & chimney units & 2 & solid fuel - need to clean \\
\cline { 2 - 5 } & $\begin{array}{l}\text { balconies and other } \\
\text { constructions }\end{array}$ & - & - \\
\cline { 2 - 5 } & $\begin{array}{l}\text { other equipment and } \\
\text { components }\end{array}$ & - & - \\
\hline \multirow{4}{*}{$\begin{array}{l}\text { lower } \\
\text { constru } \\
\text { ction }\end{array}$} & $\begin{array}{l}\text { lower construction hydro } \\
\text { isolation }\end{array}$ & - & none \\
\cline { 2 - 5 } & basement construction & - & not identified \\
\hline
\end{tabular}

\section{Conclusion}

Concluding it is possible to summarize that Brownfield Identifying Studies if they are processed for administrative areas, they are an important instrument of land protection against open landscape annexation. When they are processed properly they can serve not only as background for Land Analytic Background (UAP) processing but also as an offer for potential investors. Evaluation of constructional and technical condition of locations as whole and also more detailed classification of their individual parts is one of the most important part of these studies. This evaluation definitely affects pre-projection decision of investors and its quality can significantly affect invest costs amount - expected as well as unexpected.

\section{References}

1. Law no. 183/2006 Sb on Planning and Building Code (Prague, 2006)

2. Decree No. 500/2006 Sb., on Land Analytic Background, Urban Planning Documentation and Register Methods of Planning Activities (Prague, 2006)

3. Z. Kramářová, Ecological, functional, urban and architectural problems of brownfields in small towns (Doctoral thesis, 2006)

4. Atelier T-plan, et al., Vyhledávaci studie pro lokalizaci brownfields na území Královéhradeckého kraje (The Main Project, 2006) 